\title{
KINETIC AND EQUILIBRIUM STUDIES OF DOXORUBICIN ADSORPTION ON MCM-41-TYPE SILICA SURFACE
}

\author{
Chuiko Institute of Surface Chemistry of National Academy of Sciences of Ukraine \\ 17 General Naumov Str., Kyiv,03164,Ukraine, E-mail:roik_nadya@ukr.net
}

\begin{abstract}
Doxorubicin belongs to the most widely used anticancer chemotherapy drugs. Yet the long-term treatment with doxorubicin is associated with toxic side effects. Minimization of undesired damages of healthy cells without reducing therapeutic action of doxorubicin can be attained using drug carrier systems, particularly silica nanoparticles. The aim of this work was elucidation of the probable mechanism of interaction between doxorubicin and silica surface. The adsorption of antitumor drug on mesoporous silica nanoparticles of MCM-41-type was studied depending on the contact time, pH of phosphate buffer solution, and doxorubicin concentration by use of UV-Vis spectroscopy. Experimental kinetic curves of adsorption were compared with theoretical models of Lagergren and Ho-McKay for pseudo-first and pseudo-second order processes. High correlation coefficients indicate that the kinetics of drug adsorption on silica surface at pH 5.0 and 7.0 can be fitted by pseudo-second order kinetic model. Equilibrium adsorption of doxorubicin was analyzed by Langmuir, Freundlich, Redlich-Peterson, and Brunauer-Emmet-Teller isotherm models. BET model is the most appropriate for prediction of doxorubicin equilibrium adsorption on MCM-41 silica from solutions with $\mathrm{pH} 7.0$, whereas drug adsorption at $\mathrm{pH} 5.0$ can be described by Freundlich model. The results obtained for doxorubicin adsorption kinetics and equilibrium on MCM-41 surface can be useful for comparative analysis of chemically modified silicas effectiveness.
\end{abstract}

Keywords: MCM-41-type silica, doxorubicin, adsorption

\section{INTRODUCTION}

Doxorubicin (Dox) belongs to the most widely used anticancer chemotherapy drugs applied for medication of breast, head, liver, lung, stomach, pancreas and other cancers [1]. Yet the long-term treatment with Dox is associated with toxic side effects, risk of myelosuppression [2] and doserelated cardiotoxicity [3]. Minimization of undesired damages of healthy cells without reducing therapeutic action of Dox can be attained using drug carrier systems, particularly silica nanoparticles [4-14]. Mesoporous silicas of MCM-41 type combine such attractive properties of silica matrix as high thermal stability, biocompatibility, nontoxicity, controllable participation in chemical reactions with a wide range of modifiers with unique features provided by hexagonally arranged mesoporous structure, among which high surface area, large pore volume, uniform and tunable pores of molecular size, and accessibility of adsorption sites. All these advantages of MCM-41 silica materials make them the most promising solid supports for the formulation of biologically active systems, in particular effective drug releasing ones [15-22]. As initial MCM-41 has low loading efficiency (up to 2.6 wt. \%) [23], a better understanding of the interaction mechanism of Dox with MCM-41 will provide opportunity to realize the most effective strategy for silica surface modification depending on desired dosage and release kinetics of drug.

In the present work, to elucidate mechanism of interaction between Dox and silica surface, adsorption of antitumor drug on mesoporous MCM-41-type silica was studied depending on the contact time, $\mathrm{pH}$ of phosphate buffer solution, and Dox concentration.

\section{EXPERIMENTAL}

Tetraethyl orthosilicate (from Merck, purity $\geq 99 \%$ ), cetyltrimethylammonium bromide (from Merck, purity $\geq 97 \%$ ), doxorubicin hydrochloride (from Sigma-Aldrich, purity $\geq 98 \%$ ), phosphoric acid, sodium hydroxide, disubstituted sodium phosphate and monosubstituted potassium phosphate (all from Reakhim, pure analytical), and standard volumetric solution of hydrochloric acid (from RIAP, pure analytical) were used without additional purification.

MCM-41 silica material was synthesized by base catalyzed sol-gel condensation of tetraethyl orthosilicate in the presence of quaternary ammonium salt as structure directing agent. 
Condensation procedure was realized in water-ethanol-ammonia solution with cetyltrimethylammonium bromide as template in accordance with previously described technique $[24,25]$.

Absorption spectra of Dox buffer solutions were recorded in the $400-700 \mathrm{~nm}$ spectral range with a Specord M-40. Quartz cells with 2 and $20 \mathrm{~mm}$ path lengths were used.

The $\mathrm{pH}$ values of buffer solutions were measured by an Ionometer I-160.

The distribution diagrams of protolytic forms of Dox and silanol groups of silica surface were generated for the parameter set chosen in each simulation by the CURTIPOT program version 3.5.4 (Guts, 2010).

The effect of contact time on Dox adsorption by MCM-41 silica was studied in phosphate buffer solutions with pH 5.0 and 7.0 at $293 \mathrm{~K}$. The $0.01 \mathrm{~g}$ batches of silica material pretreated at $393 \mathrm{~K}$ for $2 \mathrm{~h}$ were placed into $5 \mathrm{ml}$ of phosphate buffer solutions with $0.138 \mathrm{mmol}$ Dox/l. The suspensions were shaken for certain time intervals, filtered through syringe filter with a $0.2 \mu \mathrm{m}$ pore size hydrophilic PVDF membrane. Dox adsorption on MCM-41 silica was determined from the values of optical density of absorption band with $\lambda_{\max }=483 \mathrm{~nm}$ using the equation:

$$
A_{t}=\frac{\left(C_{o}-C_{t}\right) V}{m},
$$

where $A_{\mathrm{t}}$ - the adsorption at time $t, \mathrm{~mol} / \mathrm{g} ; C_{\mathrm{o}}-$ the initial concentration of Dox, mol/l; $C_{t}-$ the concentration of Dox in solution at time $t, \mathrm{~mol} / \mathrm{l}$; $V$ - the volume of the solution, $1 ; m$ - the batch of silica, $g$.

Adsorption of Dox on silica surface was realized from phosphate buffer solutions with pH 5.0 and 7.0 using the multibatch technique under static conditions at $293 \mathrm{~K}$. Briefly, $0.01 \mathrm{~g}$ batches of silica material pretreated at $393 \mathrm{~K}$ for $2 \mathrm{~h}$ were placed into $5 \mathrm{ml}$ of Dox phosphate buffer solutions with concentration of drug ranging from 0.138 to $0.689 \mathrm{mmol} / \mathrm{l}$. Then, the suspensions were shaken up to equilibrium attainment $(24 \mathrm{~h})$ and filtered. The solutions were analyzed by use of spectrophotometer, and values of Dox adsorption were determined by optical density of the absorption band with maximum at $483 \mathrm{~nm}$.

\section{RESULTS AND DISCUSSION}

Synthesized silica has a particle size of 1.5-2.0 microns, hexagonally arranged porous structure of MCM-41-type silica, specific surface area of $995 \mathrm{~m}^{2} / \mathrm{g}$ (by BET method) and average pore size of $3.66 \mathrm{~nm}$ (by DFT method).

Kinetics of doxorubicin adsorption. Doxorubicin is an anthracycline antitumor antibiotic consisting of chromophoric anthraquinone and sugar moieties (Fig. 1).

Due to the presence of the amino group in Dox structure, its physicochemical properties depend essentially on the $\mathrm{pH}$. As can be seen from Fig. 2, non-ionized form of the drug is dominant at neutral and basic $\mathrm{pH}$ values, whereas the protonated one exists in acidic medium. Acidic environment is the most appropriate for adsorption studies due to Dox stability in the $\mathrm{pH}$ range from 3.0 to 6.5 [26]. However, taking into account the chemical structure of silica surface in this $\mathrm{pH}$ region (Fig. 2), it can be argued that non-ionized surface silanol groups cannot contribute to the interaction with fully protonated amino groups of Dox. As a result, we cannot expect high adsorption capacity of silica surface for Dox molecules in acidic medium. Noticeable influence of interactions between protonated or non-ionized daunosamine groups and silica surface on the adsorption process is possible at neutral $\mathrm{pH}$ values when about $50 \%$ of surface silanol groups exist in ionized state (Fig. 2). Ionized silanol groups are capable to electrostatic interactions with the positively charged amino groups of Dox. Moreover, hydrogen bond formation between neutral drug molecules and non-ionized silanol groups can take place contributing to the adsorption process.

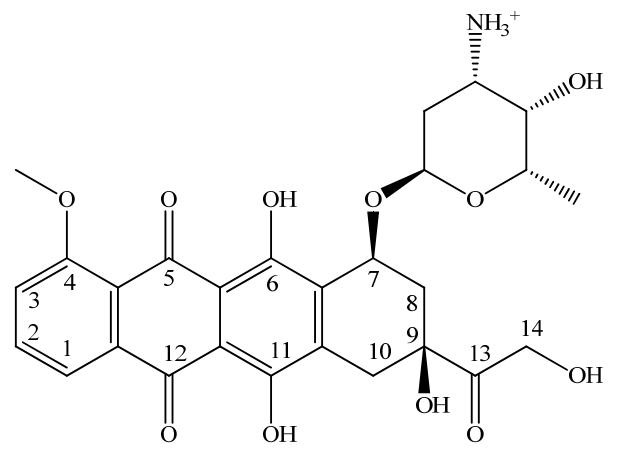

Fig. 1. Molecular structure of doxorubicin in protonated form 
In order to investigate the mechanism of Dox adsorption on MCM-41 silica the multibatch kinetic experiments were carried out at $\mathrm{pH} 5.0$ and 7.0. As can be seen in Fig. 3, adsorption capacity of MCM-41 rapidly increases during the first six hours until equilibrium is reached.

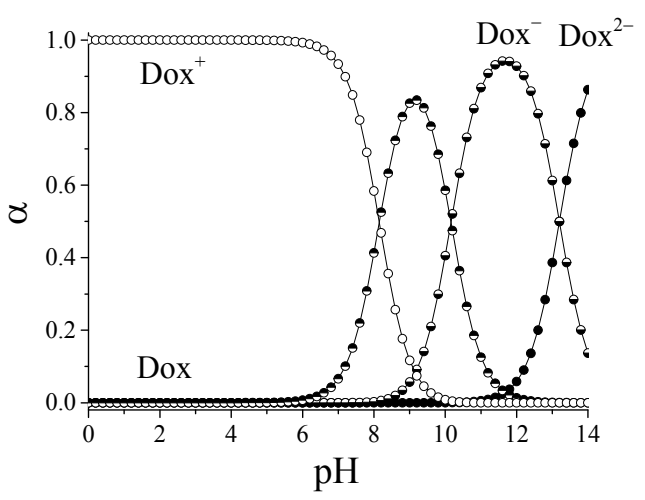

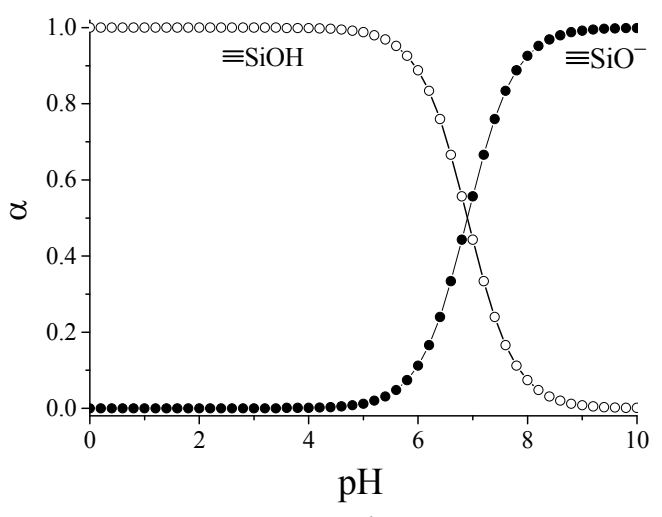

b

Fig. 2. Distribution diagrams of protolytic forms of Dox $(a)$ and surface silanol groups $(b)$ as functions of $\mathrm{pH}$

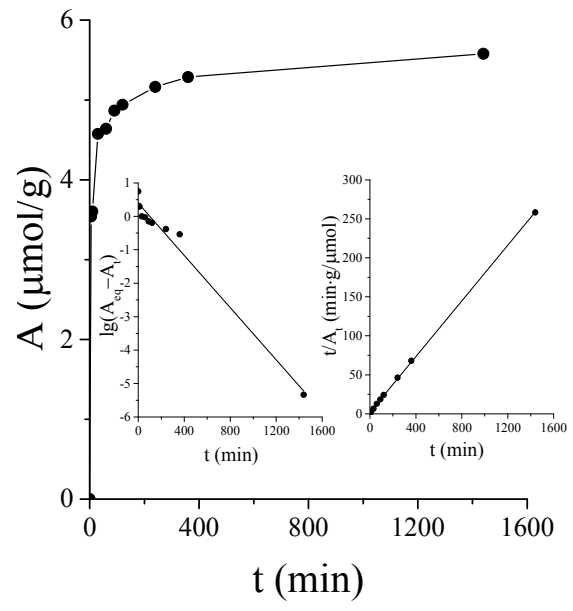

$a$

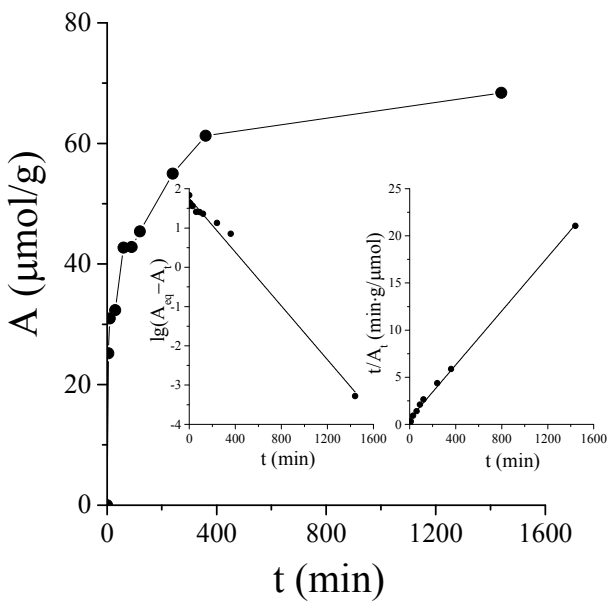

$b$

Fig. 3. Kinetic curves of Dox adsorption on MCM-41 silica at pH $5.0(a)$ and $7.0(b)$

The dependences of Dox adsorption on silica surface on the time of contact were analyzed by equations of Lagergren and Ho-McKay for pseudo-first and pseudo-second order kinetic models (Table 1), respectively. $R^{2}$ correlation coefficients close to unity indicate that adsorption of Dox on silica surface at pH 5.0 and 7.0 can be described by pseudo-second order kinetic model better than by pseudo-first one. Kinetic rate constants and amounts of Dox adsorbed from phosphate buffer solutions at equilibrium were calculated from the slope and intercept of linear plots (Table 1). It has been found that in spite of good fitting by pseudo-first order kinetic model for the whole range of contact time, the values of $A_{e q}$ evaluated by the Ho-McKay equation agree with the experimental data better than those obtained by Lagergren equation. Obviously, this discrepancy is generated by the necessity to specify the equilibrium sorption capacity in the linear equation of the pseudo-first order kinetic model. At the same time, fitting of linear form of pseudo-second order kinetic model does not require assigning the $A_{e q}$ and provides better agreement of calculated values with the experimental data.

Equilibrium adsorption of doxorubicin. The time required for equilibrium attainment was estimated from kinetic curves of Dox adsorption at different $\mathrm{pH}$ values using the pseudo-second order kinetic model. The equilibrium adsorption capacity 
of MCM-41 at pH 5.0 and 7.0 estimated by HoMcKay equation consists of 5.61 and $69.93 \mu \mathrm{mol} / \mathrm{g}$ respectively. These values are very close to the, experimental data of adsorption capacity reached after $24 \mathrm{~h}$ of contact (5.58 and $68.40 \mu \mathrm{mol} / \mathrm{g}$ ).

Adsorption isotherms, reflecting distribution of Dox between the liquid and solid phase at various concentrations of drug in phosphate buffer solutions with $\mathrm{pH} 5.0$ and 7.0, are represented in Fig. 4. It can be seen that at $\mathrm{pH} 5.0$ the adsorption grows with the increase of Dox content in the whole range of concentrations (Fig. $4 a$ ), and at $\mathrm{pH}$ 7.0 the amount of adsorbed Dox increases rapidly in the initial branch of isotherm and reaches a plateau $(0.1 \mathrm{mmol}$ Dox $/ \mathrm{g}$ silica $)$, then it grows again (Fig. 4 b).

Table 1. Kinetic parameters for Dox adsorption on MCM-41 calculated using pseudo-first and pseudo-second order kinetic models

\begin{tabular}{|c|c|c|c|}
\hline Adsorption model & Lagergren & Ho-McKay & \\
\hline equation & $\left.\lg \frac{A_{e q}}{A_{e q}-A_{t}}\right)=\frac{k_{1}}{2.303} t$ & $\frac{1}{\left(A_{e q}-A_{t}\right)}=\frac{1}{A_{e q}}+k_{2} t$ & \\
\hline linear form of equation & $\lg \left(A_{e q}-A_{t}\right)=\lg A_{e q}-\frac{k_{1}}{2.303} t$ & $\frac{t}{A_{t}}=\frac{1}{k_{2} A_{e q}^{2}}+\frac{1}{A_{e q}} t$ & \\
\hline $\begin{array}{c}\text { calculated kinetic } \\
\text { parameters }\end{array}$ & $A_{\text {eq }}$ & $A_{\mathrm{eq}}$ & $R^{2}$ \\
\hline $\mathrm{pH} 5.0$ & 0.0013 & 0.0148 & 0.999 \\
\hline $\mathrm{pH} 7.0$ & 0.0078 & 0.0004 & 0.998 \\
\hline
\end{tabular}

$A_{e q}$ and $A_{t}$-the adsorption capacity at equilibrium and at time $t, \mu m o l / g ; k_{1}$ and $k_{2}-$ the rate constants of pseudo-first and pseudo-second order adsorption processes, $1 / \mathrm{min}$ and $\mathrm{g} / \mu \mathrm{mol} \cdot \mathrm{min}$, respectively
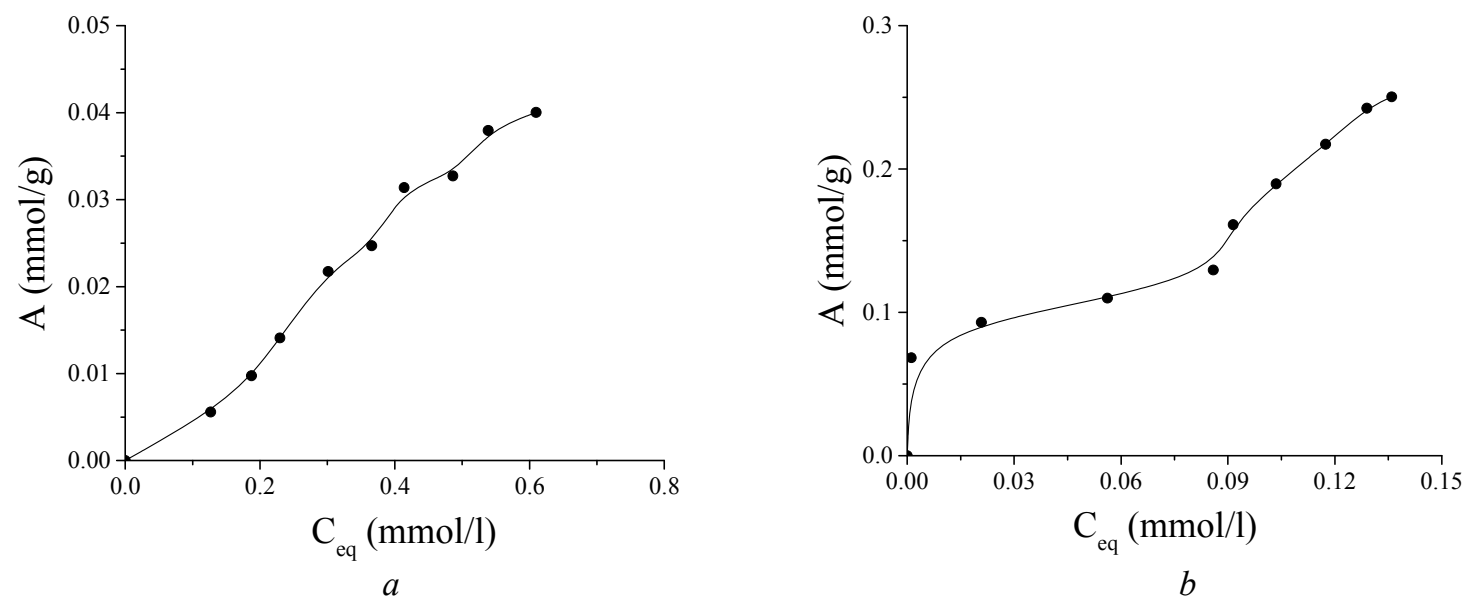

Fig. 4. Isotherms of Dox adsorption on MCM-41 silica at $\mathrm{pH} 5.0(a)$ and $7.0(b)$ obtained from multibatch adsorption experiment

In the present study, the experimental data on equilibrium Dox adsorption on MCM-41-type silicas were described by Langmuir, Freundlich, Redlich-Peterson, and Brunauer-Emmet-Teller isotherm models (Table 2). To find the most appropriate approach for the description of Dox adsorption on MCM-41 silica, adsorption parameters were estimated and experimental isotherms were compared with the calculated ones.
It is known that Langmuir isotherm model is valid for monolayer adsorption on finite number of identical sites. At the same time, Freundlich one describes the adsorption on non-uniformly distributed sites of heterogeneous surface which have a different affinity to the adsorbate molecules. To determine adsorption constants for these twoparameter isotherm models, the linear forms of Langmuir and Freundlich equations were used. The 
parameters of Dox adsorption on MCM-41 surface at different $\mathrm{pH}$ values were calculated from the slope and intercept of linear plots (Table 2). The results obtained reveal that the Dox adsorption at pH 5.0 can be better described by Freundlich adsorption model with higher value of correlation coefficient $\left(R^{2}=0.976\right)$ compared to that for Langmuir model $\left(R^{2}=0.429\right)$. In the case of Dox adsorption at $\mathrm{pH} 7.0$, correlation coefficients of Langmuir and Freundlich linear plots are too low to ascribe the occurring adsorption process to one of these two models (Table 2).
Redlich-Peterson isotherm model combines features of both Langmuir and Freundlich equations. The mechanism of adsorption process described by this approach does not follow ideal monolayer adsorption and can be considered as hybrid one. To determine adsorption constants, experimental results were analyzed with threeparameter Redlich-Peterson empirical equation using nonlinear regression (Origin, version 2015). It has been found that the value of $B$ for Dox adsorption at $\mathrm{pH} 5.0$ tends to zero proving that the adsorption obeys the Freundlich model (Table 3).

Table 2. Parameters of Dox adsorption on MCM-41 calculated using Langmuir and Freundlich models

\begin{tabular}{|c|c|c|c|c|c|c|}
\hline $\begin{array}{c}\text { Equilibrium adsorption } \\
\text { model }\end{array}$ & & Langmuir & & \multicolumn{3}{|c|}{ Freundlich } \\
\hline equation & & $A_{e q}=A_{m} \frac{K_{L} C_{e q}}{1+K_{L} C_{e q}}$ & & \multicolumn{3}{|c|}{$A_{e q}=K_{F} C_{e q}^{1 / n}$} \\
\hline linear form of equation & & $\frac{C_{e q}}{A_{e q}}=\frac{1}{K_{L} A_{m}}+\frac{C_{e q}}{A_{m}}$ & & \multicolumn{3}{|c|}{$\lg A_{e q}=\lg K_{F}+\frac{1}{n} \lg C_{e q}$} \\
\hline $\begin{array}{l}\text { calculated adsorption } \\
\text { parameters }\end{array}$ & $K_{\mathrm{L}}$ & $A_{\mathrm{m}}$ & $R^{2}$ & $\overline{K_{\mathrm{F}}}$ & $n$ & $R^{2}$ \\
\hline $\mathrm{pH} 5.0$ & 0.631 & -0.076 & 0.429 & 0.086 & 0.785 & 0.976 \\
\hline $\mathrm{pH} 7.0$ & 21.114 & 0.282 & 0.627 & 0.317 & 3.952 & 0.689 \\
\hline
\end{tabular}

$C_{e q}$ - the concentration of Dox at equilibrium, mmol/l; $K_{L}$ - the Langmuir constant related to the energy of adsorption, 1/mmol; $A_{m}$ - the monolayer adsorption capacity, mmol/g; $K_{F}$ - the Freundlich constant which corresponds to adsorption capacity, $1 / \mathrm{g} ; n$-the Freundlich constant which corresponds to adsorption intensity

Table 3. Parameters of Dox adsorption on MCM-41 calculated using Redlich-Peterson and Brunauer-Emmet-Teller models

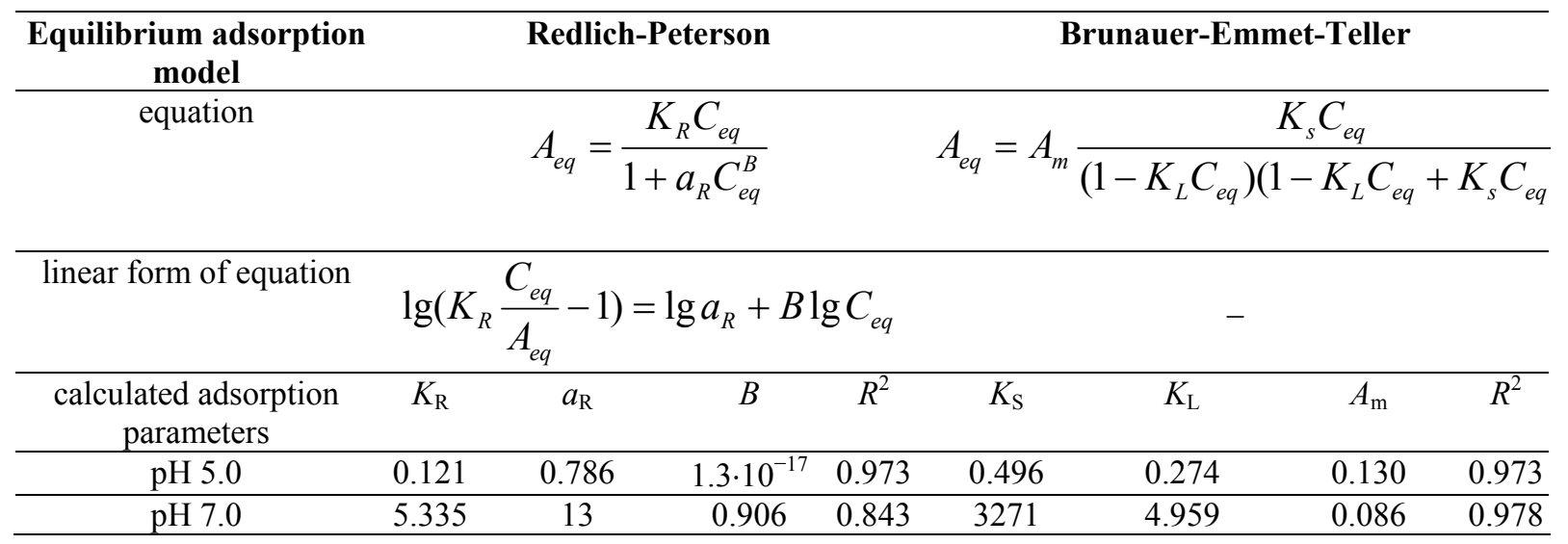

$K_{R}$ and $a_{R}$ - the Redlich-Peterson isotherm constants, l/g and l/mmol, respectively; $B$ - the exponent, which lies between 0 and 1; $K_{S}$ - the equilibrium constant of adsorbate-adsorbent interactions, $\mathrm{l} / \mathrm{mmol} ; K_{L}-$ the equilibrium constant for surface adsorption-desorption, $\mathrm{l} / \mathrm{mmol} ; A_{m}$ - the monolayer adsorption capacity, mmol/g

Brunauer-Emmet-Teller model was originally developed for gas multilayer adsorption description. Therefore, direct application of BET theory to liquid-solid phase process leads to 
erroneous results. In the present paper, a corrected form of the BET equation proposed by authors $[27,28]$ was used to model the adsorption of Dox on MCM-41 from the phosphate buffer solutions. As in the case of Redlich-Peterson model, adsorption parameters of BET equation were obtained from nonlinear regression analysis. The highest value of correlation coefficient indicates that BET model describes adsorption of Dox on MCM-41 surface from phosphate buffer solution with $\mathrm{pH} 7.0$ better than previously discussed theories (Table 3). The monolayer adsorption capacity of MCM-41 calculated using BET adsorption model is in a good agreement with experimental results (Fig. $4 b$, Table 3 ).

Taking into account chemical structure of doxorubicin and silica surface, it can be suggested that adsorption is driven mainly by physical interactions between amino groups of Dox macromolecules and silanol groups of silica surface. At pH 7.0 nearly $56 \%$ of surface silanol groups exist in ionized state, whereas $93 \%$ of Dox daunosamine groups are protonated (Fig. 2).
Ionized silanol groups are capable to electrostatic interactions with the positively charged amino groups of Dox. Contrary situation is observed at $\mathrm{pH}$ 5.0: non-ionized surface silanol groups lose their capability to interact with fully protonated aminogroups of Dox (Fig. $4 a$ ). As a result, substantial lowering of MCM-41 adsorption capacity is registered at lower $\mathrm{pH}$.

\section{CONCLUSIONS}

It has been proved that the kinetics of Dox adsorption on silica surface at $\mathrm{pH} 5.0$ and 7.0 agrees with the kinetic model of pseudo-second order. It has been found that BET model is the most appropriate for prediction of Dox equilibrium adsorption on MCM-41 silica from phosphate buffer solution with $\mathrm{pH}$ 7.0, whereas experimental data obtained at $\mathrm{pH} 5.0$ can be described by Freundlich model. The results obtained for Dox adsorption kinetics and equilibrium on MCM-41 surface can be useful for comparative analysis of chemically modified silica carriers effectiveness.

\title{
Вивчення кінетики та рівноважної адсорбції доксорубіцину на поверхні кремнезему типу МСM-41
}

\author{
Н.В. Ройк, Л.О. Бєлякова, М.О. Дзязько \\ Інститут хімії поверхні ім. О.О. Чуйка Національної академії наук України \\ вул. Генерала Наумова, 17, Київ,03164, Україна, roik_nadya@ukr.net
}

\begin{abstract}
Адсорбиію протипухлинної лікарської сполуки (доксорубіцину) наночастинками мезопористого кремнезему типу МСM-41 було вивчено в залежності від тривалості контакту, рН фосфатного буферного розчину та концентрації доксорубіцину. Експериментальні кінетичні криві адсорбиії були порівняні з теоретичними моделями Лагергрена та Хо-Маккея для прочесів псевдо-першого та псевдо-другого порядків. Високі коефіцієнти корелячії свідчать про те, щчо кінетичні криві адсорбції лікарської сполуки на поверхні кремнезему при рН5.0 та 7.0 можуть бути описані кінетичною моделлю псевдо-другого порядку. Рівноважну адсорбцію доксорубічину було проаналізовано за допомогою моделей ізотерм Ленгмюра, Фрейндліха, Редліха-Петерсона та Брунауера-Еммета-Теллера. Модель БЕТ найбільше придатна для опису рівноважної адсорбиії доксорубіцину МСМ-41 кремнеземом з розчинів з рH 7.0, тоді як адсорбиія лікарської сполуки при рН 5.0 відповідає моделі Фрейндліха.
\end{abstract}

Ключові слова: кремнезем типу МСM-41, доксорубіичин, адсорбиія 


\title{
Изучение кинетики и равновесной адсорбции доксорубицина на поверхности кремнезема типа МСМ-41
}

\author{
Н.В. Роик, Л.А. Белякова, М.А. Дзязько
}

Институт химии поверхности им. А.А. Чуйко Национальной академии наук Украинь ул. Генерала Наумова, 17, Киев, 03164, Украина, roik_nadya@ukr.net

\begin{abstract}
Адсорбция противоопухолевого лекарственного соединения (доксорубицина) наночастицами мезопористого кремнезема типа МСМ-41 была изучена в зависимости от длительности контакта, рН фосфатного буферного раствора и концентрации доксорубицина. Экспериментальные кинетические кривые адсорбции были сопоставлены с теоретическими моделями Лагергрена и Хо-Маккея для процессов псевдопервого и псевдо-второго порядков. Высокие коэффициенты корреляции свидетельствуют о том, что кинетические кривые адсорбции лекарства на поверхности кремнезема при рН5.0 и 7.0 могут быть описаны кинетической моделью псевдо-второго порядка. Равновесная адсорбция доксорубицина была проанализирована с помощью моделей изотерм Ленгмюра, Фрейндлиха, Редлиха-Петерсона и БрунауэраЭммета-Теллера. Модель БЭТ наиболее подходит для описания равновесной адсорбции доксорубицина МСМ-41 кремнеземом из растворов с рН 7.0, в то время как адсорбциия лекарства при рН 5.0 соответствует модели Фрейндлиха.
\end{abstract}

Ключевые слова: кремнезем типа МСМ-41, доксорубицин, адсорбичия

\section{REFERENCES}

1. Perry M.C. The Chemotherapy Source Book, 2nd edn. (Baltimore: Williams@Wilkins, 1996).

2. Bally M.B., Nayar R., Masin D., Cullis P.R., Mayer L.D. Studies on the myelosuppressive activity of doxorubicin entrapped in liposomes. Cancer Chemotherapy and Pharmacology. 1990. 27(1): 13.

3. Sumeet G., Swati M. Doxorubicin Induced Cardiotoxicity: The Spice Retreat. (Saarbruecken: Lambert Academic Publishing, 2014).

4. Roik N.V., Belyakova L.A. Cyclodextrin-based drug stabilizing system. J. Mol. Struct. 2011. 987(1-3): 225.

5. Lee C.-H., Cheng S.-H., Huang I.-P., Souris J.S., Yang C.-S., Mou C.-Y., Lo L.-W. Intracellular pH-responsive mesoporous silica nanoparticles for the controlled release of anticancer chemotherapeutics. Angew. Chem. 2010. 122(44): 8390.

6. Meng H., Xue M., Xia T., Zhao, Y.-L., Tamanoi, F., Stoddart, J.F., Zink,J.I., Nel A.E. Autonomous in vitro anticancer drug release from mesoporous silica nanoparticles by $\mathrm{pH}$-sensitive nanovalves. J. Am. Chem. Soc. 2010. 132(36): 12690.

7. Gao Y., Chen Y., Ji X., He X., Yin Q., Zhang Z., Shi J., Li Y. Controlled intracellular release of doxorubicin in multidrug-resistant cancer cells by tuning the shell-pore sizes of mesoporous silica nanoparticles. Am. Chem. Sci. 2011. 5(12): 9788.

8. Knezevic N.Z., Trewyn B.G., Lin V.S.-Y. Light- and pH-responsive release of doxorubicin from a mesoporous silica-based nanocarrier. Chem. Eur. J. 2011. 17(12): 3338.

9. Roik N.V., Belyakova L.A. Interaction of supramolecular centers of silica surface with aromatic amino acids. J. Coll. Interf. Sci. 2011. 362(1): 172.

10. Zhang X., Clime L., Roberge H., Normandin F., Yahia L.H., Sacher E., Veres T. pH-Triggered doxorubicin delivery based on hollow nanoporous silica nanoparticles with free-standing superparamagnetic $\mathrm{Fe}_{3} \mathrm{O}_{4}$ cores. J. Phys. Chem. C. 2011. 115(5): 1436.

11. Gu J., Su S., Zhu M., Li Y., Zhao W., Duan Y., Shi J. Targeted doxorubicin delivery to liver cancer cells by PEGylated mesoporous silica nanoparticles with a $\mathrm{pH}$-dependent release profile. Micropor. Mesopor. Mater. 2012. 161: 160 .

12. Chen Y., Yang W., Chang B., Hu H., Fang X., Sha X. In vivo distribution and antitumor activity of doxorubicin-loaded N-isopropylacrylamide-co-methacrylic acid coated mesoporous silica nanoparticles and safety evaluation. Europ. J. Pharm. Biopharm. 2013. 85(3): 406. 
13. Hu X., Hao X., Wu Y., Zhang J., Zhang X., Wang P.C., Zou G., Liang X.-J. Multifunctional hybrid silica nanoparticles for controlled doxorubicin loading and release with thermal and $\mathrm{pH}$ dual response. J. Mater. Chem. B. 2013. 1: 1109.

14. Mishra A.K., Pandey H., Agarwal V., Ramteke P.W., Pandey A.C. Nanoengineered mesoporous silica nanoparticles for smart delivery of doxorubicin. J. Nanopart. Res. 2014. 16: 2515.

15. Lee C.-H., Cheng S.-H., Huang I.-P., Souris J.S., Yang C.-S., Mou C.-Y., Lo L.-W. Intracellular pH-responsive mesoporous silica nanoparticles for the controlled release of anticancer chemotherapeutics. Angew. Chem. 2010. 122: 8390.

16. Meng H., Xue M., Xia T., Zhao Y.-L., Tamanoi F., Stoddart J.F., Zink J.I., Nel A.E. Autonomous in vitro anticancer drug release from mesoporous silica nanoparticles by $\mathrm{pH}$-sensitive nanovalves. J. Am. Chem. Soc. 2010. 132: 12690.

17. Knezevic N.Z., Trewyn B.G., Lin V.S.-Y. Light- and pH-responsive release of doxorubicin from a mesoporous silica-based nanocarrier. Chem. Eur. J. 2011. 17: 3338.

18. Lee J.E., Lee D.J., Lee N., Kim B.H., Choi S.H., Hyeon T. Multifunctional mesoporous silica nanocomposite nanoparticles for $\mathrm{pH}$ controlled drug release and dual modal imaging. J. Mater. Chem. 2011. 21: 16869.

19. Yuan L., Tang Q., Yang D., Zhang J.Z., Zhang F., Hu J. Preparation of pH-responsive mesoporous silica nanoparticles and their application in controlled drug delivery. J. Phys. Chem. C. 2011. 115: 9926.

20. Gu J., Su S., Zhu M., Li Y., Zhao W., Duan Y., Shi J. Targeted doxorubicin delivery to liver cancer cells by PEGylated mesoporous silica nanoparticles with a $\mathrm{pH}$-dependent release profile. Micropor. Mesopor. Mater. 2012. 161: 160 .

21. Hu X., Hao X., Wu Y., Zhang J., Zhang X., Wang P.C., Zou G., Liang X.-J. Multifunctional hybrid silica nanoparticles for controlled doxorubicin loading and release with thermal and $\mathrm{pH}$ dual response. J. Mater. Chem. B. 2013. 1: 1109.

22. Knezevic N.Z., Ruiz-Hernandez E., Hennink W.E., Vallet-Regi M. Magnetic mesoporous silica-based core/shell nanoparticles for biomedical applications. RSC Adv. 2013. 3: 9584.

23. Kim M.S., Jeon J.B., Chang J.Y. Selectively functionalized mesoporous silica particles with the PEGylated outer surface and the doxorubicin-grafted inner surface: improvement of loading content and solubility. Micropor. Mesopor. Mater. 2013. 172: 118.

24. Roik N.V., Belyakova L.A. Sol-gel synthesis of MCM-41 silicas and selective vapor-phase modification of their surface. J. Solid State Chem. 2013. 207: 194.

25. Roik N.V., Belyakova L.A. Chemical design of $\mathrm{pH}$-sensitive nanovalves on outer surface of mesoporous silicas for controlled storage and release of aromatic amino acid. J. Solid State Chem. 2014. 215: 284.

26. Florey K., ed. Analytical Profiles of Drug Substances. V. 9 (New York: Academic Press Inc., 1980).

27. Gritti F., Guiochon G. New thermodynamically consistent competitive adsorption isotherm in RPLC. J. Coll. Int. Sci. 2003. 264(1): 43.

28. Ebadi A., Mohammadzadeh J.S.S., Khudiev A. What is correct form of BET isotherm for modeling liquid phase adsorption. Adsorption. 2009. 15(1): 65. 